\title{
Effect of bamboo leaf ash on cement stabilization of Makurdi shale for use as flexible pavement construction material
}

\author{
Iorliam, A. Y., Agbede, I. O, and Joel, M \\ Department of Civil Engineering, University of Agriculture, Makurdi, Nigeria. \\ amosyalas2007@yahoo.com, femiagbede2002@yahoo.com and manassehjoel@yahoo.com
}

\begin{abstract}
A study was carried out on the cement stabilization of Makurdi shale treated with bamboo leaf ash (BLA), for use as flexible pavement construction material. Classification, Compaction, Consistency, California Bearing Ratio (CBR) and unconfined compressive strength (UCS) tests, were conducted on Makurdi shale specimen treated with Cement and BLA in combined incremental order of $2 \%$ up to $14 \%$ cement, and $4 \%$ up to $20 \%$ BLA of dry weight of soil sample respectively. Results of tests showed that Makurdi shale can be classified as an A-7-6, $\mathrm{CH}$ and high swell potential soil by the AASHTO, USCS and NBRRI classification systems respectively. The plasticity index $(\mathrm{Pl})$ reduced from $39.4 \%$ for untreated Makurdi shale to $4.7 \%$ at $14 \%$ cement $+20 \%$ BLA. Maximum dry density (MDD) of untreated shale increased from 1.49 $\mathrm{Mg} / \mathrm{m}^{3}$ to a peak value of $1.80 \mathrm{Mg} / \mathrm{m}^{3}$ at $0 \% \mathrm{BLA}+14 \%$ cement. While, the optimum moisture content (OMC) of shale increased from $14.5 \%$ to $33.1 \%$ at $14 \%$ Cement $+20 \%$ BLA. Maximum soaked CBR and 7 day UCS values of $80 \%$ and $1783.9 \mathrm{kN} / \mathrm{m}^{2}$ was obtained at $14 \%$ Cement + $20 \%$ BLA. Based on the results of the different tests, the use of Makurdi shale treated with $14 \%$ cement $+20 \%$ BLA are recommended for use as sub-base materials in flexible pavement.
\end{abstract}

Keywords: Cement, Bamboo leaf ash, stabilization, Flexible pavement, Makurdi shale

\section{INTRODUCTION}

Shale is essentially a clayey material, which is very likely to break down in the presence of moisture and frost (O' Flaherty, 1974). Since shale is highly clayey in nature, it is subjected to swelling during the rainy season and shrinking during the dry season. Shale is a notoriously unpredictable material, in which a number of failures have been reported involving settlement and shear failure of compacted shale embankments (Abeyesekera et al., 1978).

Makurdi town, the headquarters of Benue State in Nigeria is extensively underlain with shale as confirmed by Agbede and Smart (2007). The shale deposit, like any other expansive soil, has caused extensive failure to buildings and roads in Makurdi. These defects are prominent on buildings in Makurdi town in form of cracks ranging from fraction of millimeters to about $10 \mathrm{~mm}$, thereby reducing the lifespan of these structures and posing threat to lives and properties. (See Plates $1 \& 2$ ). This is in agreement with the observation in South Africa and Egypt where serious cracks were recorded on buildings founded on shale (El-Shoby et al., 1987; Williams, 1980). 
Am. J. Sci. Ind. Res., 2012, 3(3): 166-174

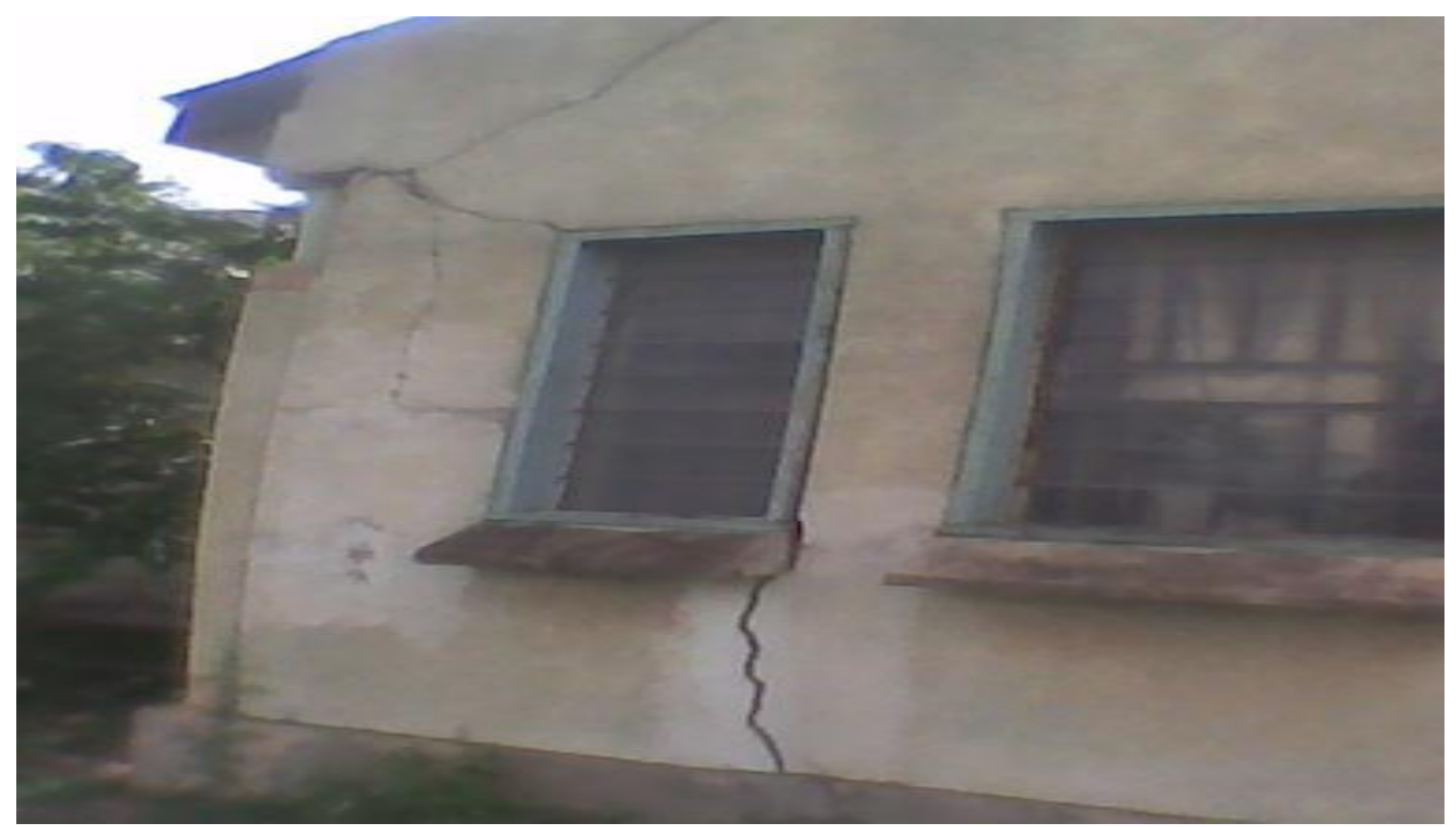

Plate 1: Cracks on Building founded on shale deposits located at the College of Engineering, University of Agriculture, Makurdi, Benue State, Nigeria.

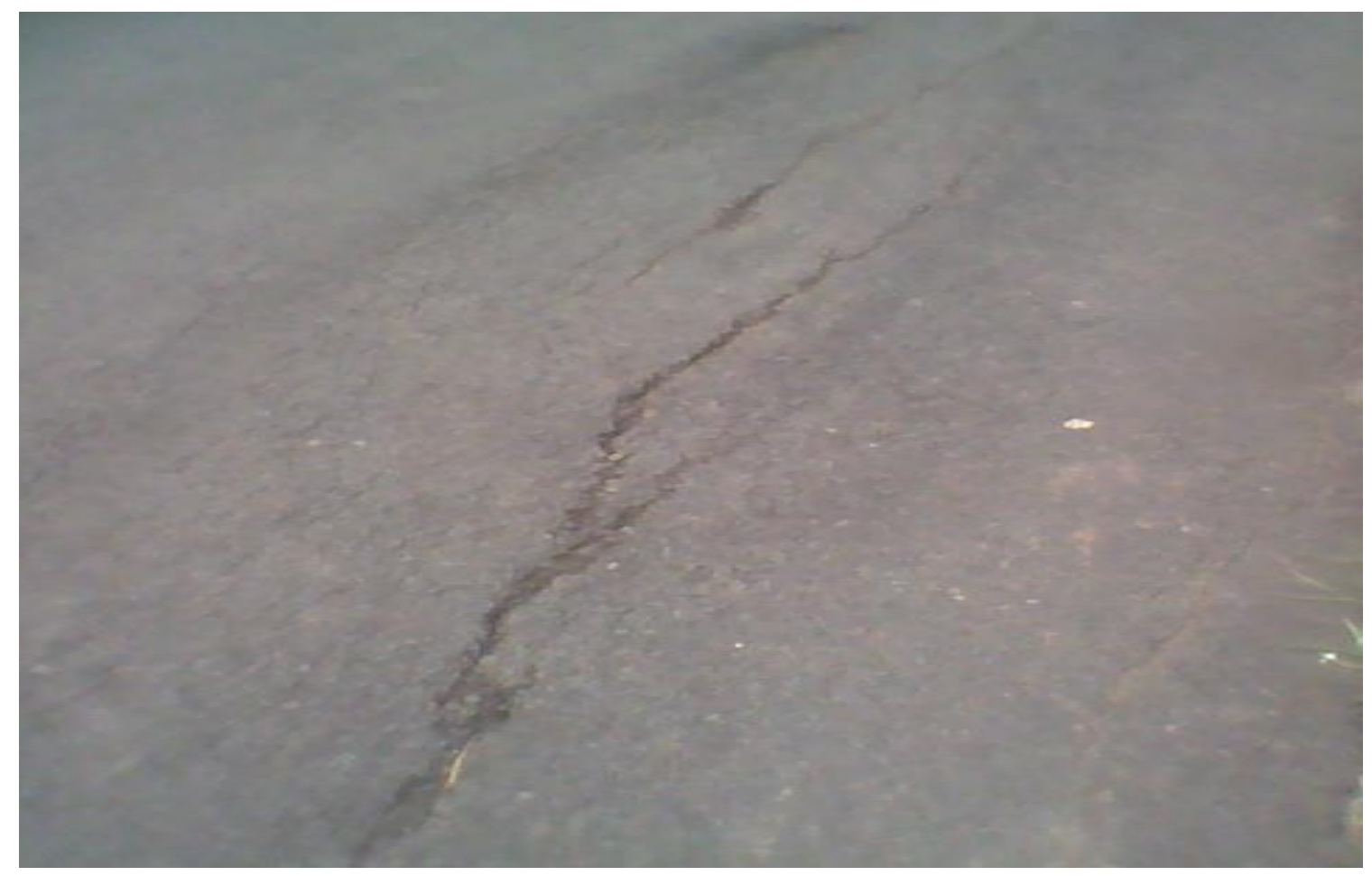

Plate 2: Failed portion of the intra campus Road, University of Agriculture, Makurdi, Benue State, Nigeria. 


\section{GEOLOGY OF THE STUDY AREA}

Makurdi formation is comprised of three zones, the lower Makurdi sandstone: the upper Makurdi sandstone and the Wadata limestone (Nwajide, 1982). The lower Makurdi sandstone, which could be found around the Makurdi Airport, consists of sandstones and mudrocks. They are micaceous throughout with mudrocks predominating. The upper Makurdi sandstone is similar to the lower sandstone but with mudsrocks being relatively less common, as found around the North Bank area of Makurdi. Sandstones and shales outcrop prominently and the sandstone range from very fine to medium in grain size. In this zone, there are shale units of mainly fissile siltstone, usually brownish grey in colour and often abundantly micaceous.

Wadata limestone also consists of several limestone occurrences; most outcrops are shelly limestone often closely associated with mudrocks which is the most extensive member of the Makurdi formation (Nwajide, 1982). The sandstones in this zone are generally fine to medium grained, moderately sorted, micaceous and feldsphatic. In some parts, they are calcareous, micaceous and shelly. Various types of cement like iron oxides, silica, carbonates and clay were shown to be present in the Makurdi sandstone.

Justification of the study: In Makurdi and other parts of Nigeria where shale deposits are encountered, it has caused a lot of damages, and threats to buildings and roads found on them (See Plates 1 and 2). Most shale deposits cover large areas, resulting in shortage of good construction materials in such locations. The need to make the unsuitable natural soil fit for use in engineering work at economic cost makes the research on stabilization of Makurdi shale so important, due to high cost of haulage; avoiding or by-passing such problem soil is difficult.

In attempts to provide solution to the challenges posed by shale, several works have been carried out on shale. Agbede and Smart (2007) worked on Makurdi shale and reported high percentage content of mixed-layer illite/smectite responsible for the expansive nature of the soil and recommended a foundation other than the conventional strip foundation. Agbede and Joel (2011) reported the effective stabilization of the Makurdi shale and good bricks quality from heat treatment of natural
Makurdi shale treated with carbide waste admixtures.

Others used lime alone or in combination with cement or with sand and reported significant improvement in the geotechnical properties of Igumale shale (Joel and Agbede, 2008a; Joel and Agbede, 2010; Joel and Agbede, 2008b). However, no study has explored the treatment of Makurdi shale with bamboo leaf ash (BLA). This has necessitated the research on the improvement of Makurdi shale with cement-bamboo leaf ash (C$B L A)$. The aim of the study is to investigate the effect of C-BLA on some geotechnical properties of Makurdi shale for its suitability in road work.

BLA is reported a good pozzolanic material, which reacts with calcium hydroxide forming calcium silicate hydrate (Dwivedi et al., 2006). Amu and Adetuberu (2010) used BLA to treat lateritic soils and recorded significant improvement in its strength properties.

The use of BLA stems from, the need to reduce the cost of waste disposal, use cheap and economic soil stabilizer in geotechnical and road work, as well as make the unsuitable natural soils fit for use in engineering work at economic cost, especially where avoiding or by-passing them is difficult.

\section{MATERIALS AND METHODS}

The soil used in the study was obtained from a borrow pit at a depth of 1.5 metres of shale outcrop located in College of Engineering, University of Agriculture Makurdi. Makurdi town is located on $7^{\circ} 43^{\prime} 50^{\prime \prime} \mathrm{N}$ and $8^{\circ} 32^{\prime} 10^{\prime \prime} \mathrm{E}$, on the geographical map of Nigeria (http://en.wikipedia.org/wiki/Makurdi, 2012). While ordinary Portland cement (OPC) was obtained from Makurdi in Benue State, Nigeria, the bamboo leaves were obtained in Otukpo, where the leaves are much available as waste (See Plate 3). The leaves were sun dried, burnt in an open air and then heated in furnace at $600{ }^{\circ} \mathrm{C}$ for two hours at the Metallurgy Laboratory, Department of Mechanical Engineering, University of Agriculture, Makurdi. Laboratory tests were performed on the sample in accordance with BS 1377 (1990) for the natural shale and BS 1924 (1990) for shale treated with C-BLA. The tests performed on the soil with CBLA include, Atterberg limits, compaction, UCS and CBR tests. The CBR tests were conducted in accordance with the Nigerian General Specification 
(1997) which stipulates that specimens be cured in the dry for six days and then soaked for 24 hours before testing. Compaction was carried out at the energy level of the British standard (BS) light compactive effort only, because this is easily achieved in the field. The resistance to loss in strength was determined as a ratio of the UCS value of specimens cured for 7 days under controlled conditions, which were subsequently immersed in water for another 7 days to the UCS value of specimens cured for 14 days. X -ray fluorescence analysis was carried out on the BLA, OPC and shale samples, using Philips PW 1450/20 spectrometer to aid in the determination of their oxide composition.

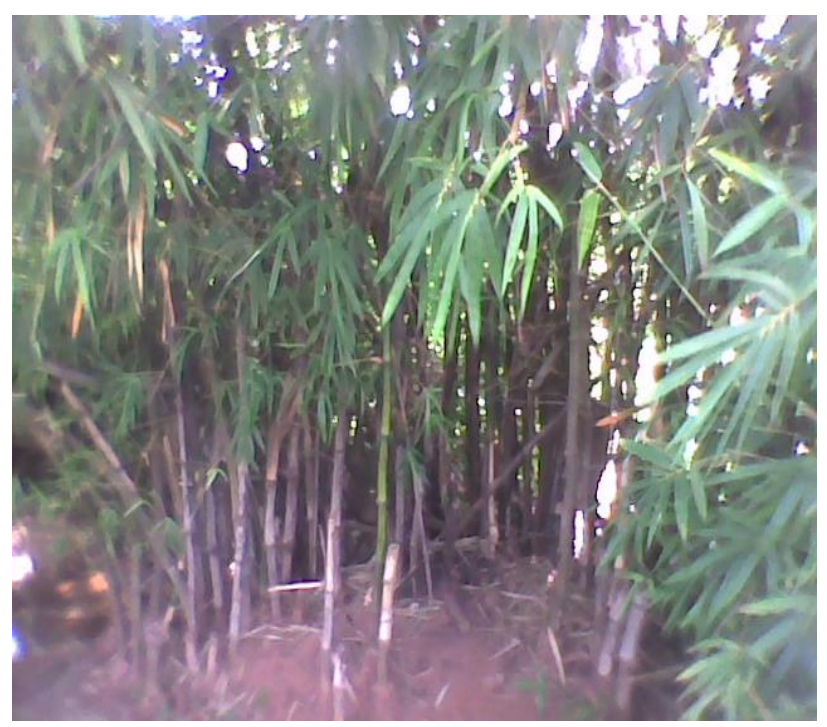

Plate 3: Bamboo Tree farm in Otukpo, Benue State, Nigeria.

\section{RESULTS AND DISCUSSIONS}

The index property of natural Makurdi shale is summarized in Table 1. The soil is an $\mathrm{A}-7-6, \mathrm{CH}$ and high swell potential soil by the AASHTO (ASTM, 1994), USCS (1962) and NBRRI (1983) classification system respectively. The test results showed that the natural soil was not suitable for use as sub-base or base course materials and even requires a modified layer above it as a sub-grade soil. Table 2 shows the oxide compositions of bamboo leaf ash (BLA), cement and Makurdi shale. The results confirm the presence of abundant silica and calcium oxide in BLA and cement respectively for stabilization of Makurdi shale. The plasticity index, CBR, UCS and durability test result of Makurdi shale treated with different percentages of BLA and cement is as summarized in Table 3.

Table 1: Results of Tests on Natural Makurdi Shale

\begin{tabular}{ll}
\hline Property & Quantity \\
\hline Percentage passing BS Sieve & 87 \\
No. 200 (\%) & 30.43 \\
Natural moisture content (\%) & 46.90 \\
Liquid limit (\%) & 31.0 \\
Plastic limit (\%) & 14.68 \\
Plasticity index (\%) & 12.10 \\
Linear shrinkage (\%) & 30 \\
Free swell (\%) & 2.42 \\
Specific gravity & $\mathrm{A}-7-6$ \\
AASHTO classification & $\mathrm{CH}$ \\
USCS classification & high swell \\
NBRRI classification & potential soil \\
Maximum dry density (Mg/m ${ }^{3}$ ) & 1.49 \\
Optimum moisture content $(\%)$ & 23.50 \\
7 day Unconfined compressive & 53.52 \\
strength (kN/m ${ }^{2}$ ) & 2 \\
California bearing ratio, after & \\
(after 24 hours soaking) & \\
\hline
\end{tabular}

Table 2: Chemical Compositions of Cement, Makurdi Shale and BLA used

\begin{tabular}{|c|c|c|c|}
\hline \multirow{3}{*}{$\begin{array}{l}\text { Chemical } \\
\text { Composition }\end{array}$} & \multirow{2}{*}{\multicolumn{3}{|c|}{$\begin{array}{l}\text { Concentration } \\
\text { weight) }\end{array}$}} \\
\hline & & & \\
\hline & \multicolumn{2}{|c|}{$\begin{array}{l}\text { Cement } \\
\text { BLA }\end{array}$} & Makurdi shale \\
\hline $\mathrm{SiO}_{2}$ & 19.53 & 49.02 & 44.50 \\
\hline $\mathrm{P}_{2} \mathrm{O}_{5}$ & - & 0.50 & 3.80 \\
\hline $\mathrm{SO}_{3}$ & - & - & 1.00 \\
\hline $\mathrm{K}_{2} \mathrm{O}$ & 0.62 & 1.85 & 10.10 \\
\hline $\mathrm{CaO}$ & 62.0 & 0.26 & 9.89 \\
\hline $\mathrm{TiO}_{2}$ & 0.37 & 1.98 & 1.29 \\
\hline $\mathrm{V}_{2} \mathrm{O}_{5}$ & - & - & 0.0049 \\
\hline $\mathrm{Cr}_{2} \mathrm{O}_{3}$ & - & - & 0.02 \\
\hline $\mathrm{MnO}$ & - & 0.03 & 0.44 \\
\hline $\mathrm{Fe}_{2} \mathrm{O}_{3}$ & 4.0 & 8.37 & 3.26 \\
\hline $\mathrm{Al}_{2} \mathrm{O}_{3}$ & 6.0 & 25.24 & - \\
\hline $\mathrm{MgO}$ & 1.40 & 1.16 & - \\
\hline $\mathrm{Na}_{2} \mathrm{O}$ & 0.50 & 2.57 & - \\
\hline LOI & 2.0 & - & 25.00 \\
\hline
\end{tabular}


Am. J. Sci. Ind. Res., 2012, 3(3): 166-174

Table 3: Plasticity, Durability and Strength Indices of Makurdi Shale with C - BLA Combinations.

\begin{tabular}{|c|c|c|c|c|c|c|c|c|c|}
\hline \multicolumn{2}{|c|}{ Cement Content (\%) } & 0 & 2 & 4 & 6 & 8 & 10 & 12 & 14 \\
\hline $0 \%$ & $\mathrm{PI}$ & 39.4 & 33.5 & 29.5 & 29.0 & 21.5 & 15.3 & 13.0 & 12.6 \\
\hline \multirow[t]{3}{*}{ BLA } & CBR (\%) & 6 & 12 & 15 & 18 & 21 & 24 & 25 & 30 \\
\hline & 7dUCS & 53.52 & 192.23 & 216.98 & 287.35 & 363.79 & 376.00 & 389.20 & 472.93 \\
\hline & $\mathrm{R}(\%)$ & 20.63 & 33.50 & 46.30 & 53.40 & 64.80 & 69.30 & 73.60 & 78.00 \\
\hline $4 \%$ & $\mathrm{PI}$ & 33.2 & 27.7 & 27.0 & 23.2 & 18.9 & 13.6 & 12.7 & 10.9 \\
\hline \multirow[t]{3}{*}{ BLA } & CBR (\%) & 9 & 15 & 16 & 18 & 21 & 37 & 54 & 62 \\
\hline & 7dUCS & 88.11 & 209.21 & 332.93 & 350.44 & 802.96 & 1167.37 & 1257.17 & 1284.0 \\
\hline & $\mathrm{R}(\%)$ & 40.60 & 42.30 & 48.30 & 52.30 & 67.00 & 76.40 & 82.56 & 89.00 \\
\hline $8 \%$ & PI & 29.90 & 27.60 & 22.50 & 21.30 & 15 & 13.0 & 10.2 & 8.70 \\
\hline \multirow[t]{3}{*}{ BLA } & CBR (\%) & 12 & 15 & 16 & 17 & 23 & 42 & 54 & 67 \\
\hline & 7dUCS & 89.00 & 267.59 & 361.63 & 386.52 & 822.30 & 1112.64 & 1264.35 & 1312.0 \\
\hline & $\mathrm{R}(\%)$ & 58.20 & 60.35 & 63.80 & 65.70 & 75.00 & 85.00 & 79.30 & 93.3 \\
\hline $12 \%$ & $\mathrm{PI}$ & 27.70 & 24.4 & 19.2 & 13.2 & 13.7 & 12.7 & 9.8 & 7.6 \\
\hline \multirow[t]{3}{*}{ BLA } & CBR (\%) & 14 & 16 & 18 & 19 & 25 & 42 & 59 & 74 \\
\hline & $7 d U C S$ & 107.0 & 269.75 & 372.14 & 475.71 & 832.58 & 1129.82 & 1665.0 & 1669.6 \\
\hline & $\mathrm{R}(\%)$ & 63.50 & 65.70 & 66.00 & 68.30 & 74.50 & 89.30 & 91.40 & 93.40 \\
\hline $16 \%$ & PI & 27.6 & 23.3 & 18.5 & 13.6 & 12.8 & 10.4 & 9.4 & 6.9 \\
\hline \multirow[t]{3}{*}{ BLA } & CBR (\%) & 17 & 18 & 19 & 22 & 26 & 43 & 61 & 79 \\
\hline & 7dUCS & 148.7 & 271.91 & 386.38 & 487.87 & 852.80 & 1165.49 & 1694.72 & 1736.4 \\
\hline & $\mathrm{R}(\%)$ & 69.60 & 73.30 & 75.40 & 79.30 & 86.50 & 90.60 & 92.70 & 93.60 \\
\hline $20 \%$ & PI & 23.2 & 22.7 & 13.7 & 12.9 & 10.2 & 9.0 & 5.9 & 4.70 \\
\hline \multirow[t]{3}{*}{ BLA } & CBR (\%) & 18 & 19 & 20 & 24 & 30 & 48 & 66 & 80 \\
\hline & 7dUCS & 154.6 & 274.61 & 393.09 & 495.66 & 866.95 & 1177.39 & 1699.00 & 1783.9 \\
\hline & $\mathrm{R}(\%)$ & 72.30 & 83.00 & 85.30 & 88.50 & 90.2 & 91.90 & 93.0 & 95.30 \\
\hline
\end{tabular}

$\mathrm{PI}=$ Plasticity Index, CBR = California Bearing Ratio,

$7 \mathrm{~d}$ UCS $=$ Seven day Unconfined Compressive Strength, $\mathrm{kN} / \mathrm{m}^{2}, \mathrm{R} \%=$ Resistance to loss in Strength

Effect of Cement - Bamboo Leaf Ash (C BLA) on Consistency Properties of Makurdi Shale.

The addition of cement and BLA to Makurdi shale improved its consistency properties, as the plasticity index reduced from $39.4 \%$ for untreated Makurdi shale to $4.7 \%$ at $14 \%$ cement plus $20 \%$ BLA (Figure 1). This is probably due to higher release of $\mathrm{Ca}^{2+}$ and $\mathrm{Si}^{2+}$ cations with increased cement + BLA.

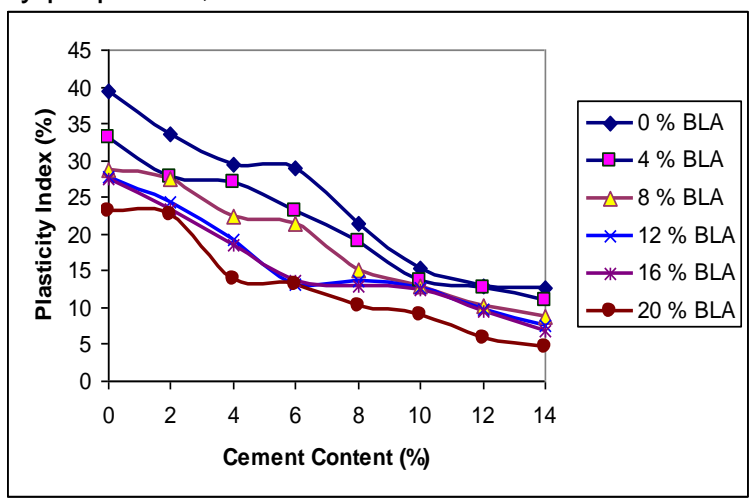

Figure 1: Variation of Plasticity Index of Makurdi Shale treated with Cement and BLA Content. 
Effect of Cement - Bamboo Leaf Ash (C-BLA) on Compaction Characteristics of Makurdi Shale: The effect of C-BLA content on the maximum dry density (MDD) and optimum moisture content (OMC) of Makurdi shale is shown in Figures 2 and 3 respectively. The MDD and OMC increased with C-BLA content for all percentages. The increase in the MDD from $1.49 \mathrm{Mg} / \mathrm{m}^{3}$ at $0 \% \mathrm{C}-\mathrm{BLA}$ content to a peak MDD value of $1.80 \mathrm{Mg} / \mathrm{m}^{3}$ at $0 \% \mathrm{BLA}+14 \%$ cement, is as a result of the combined action of cement and BLA; while BLA released more silica, cement released calcium oxide that caused the flocculation and agglomeration of clay particles as well as plugs the void and bind the particles together. The OMC increased with higher C-BLA treated up to $14 \%$ Cement $+20 \%$ BLA, from $14.5 \%$ to $33.1 \%$. The increased OMC with higher C-BLA is as a result of extra water required for the hydration of cement and BLA.

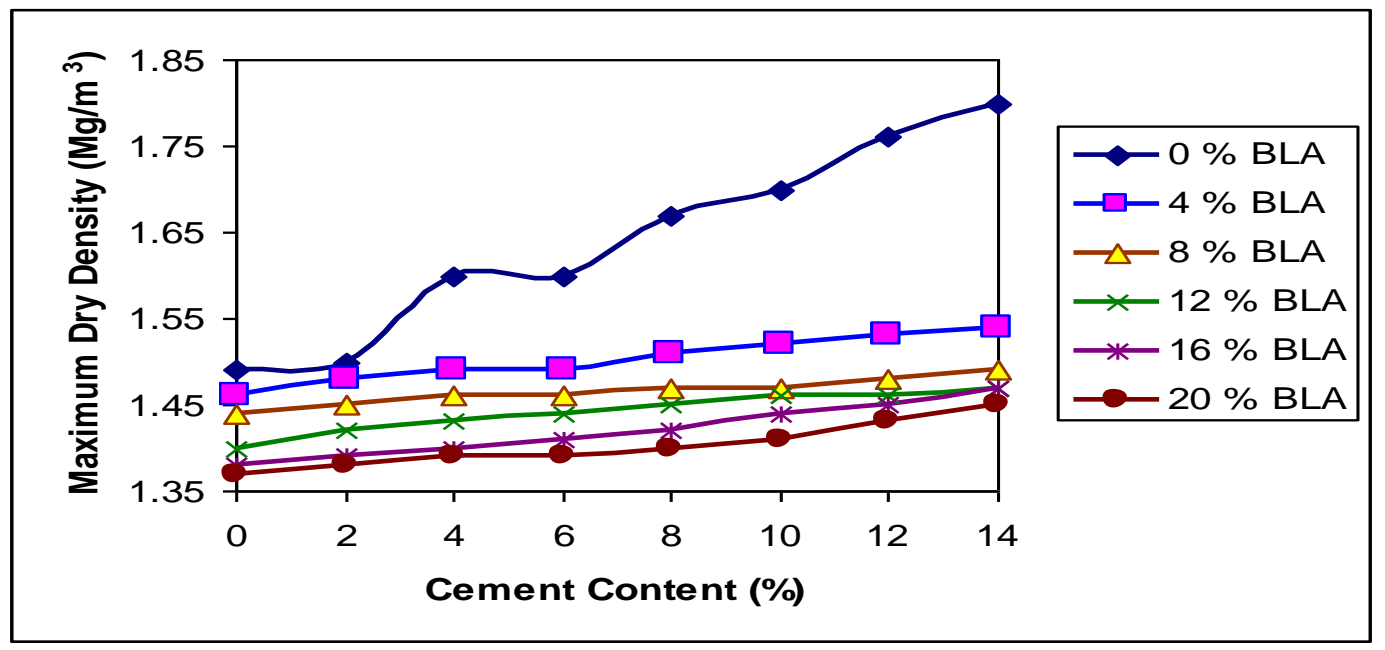

Figure 2: Variation of Maximum Dry Density of Makurdi Shale treated with Cement and BLA Content.

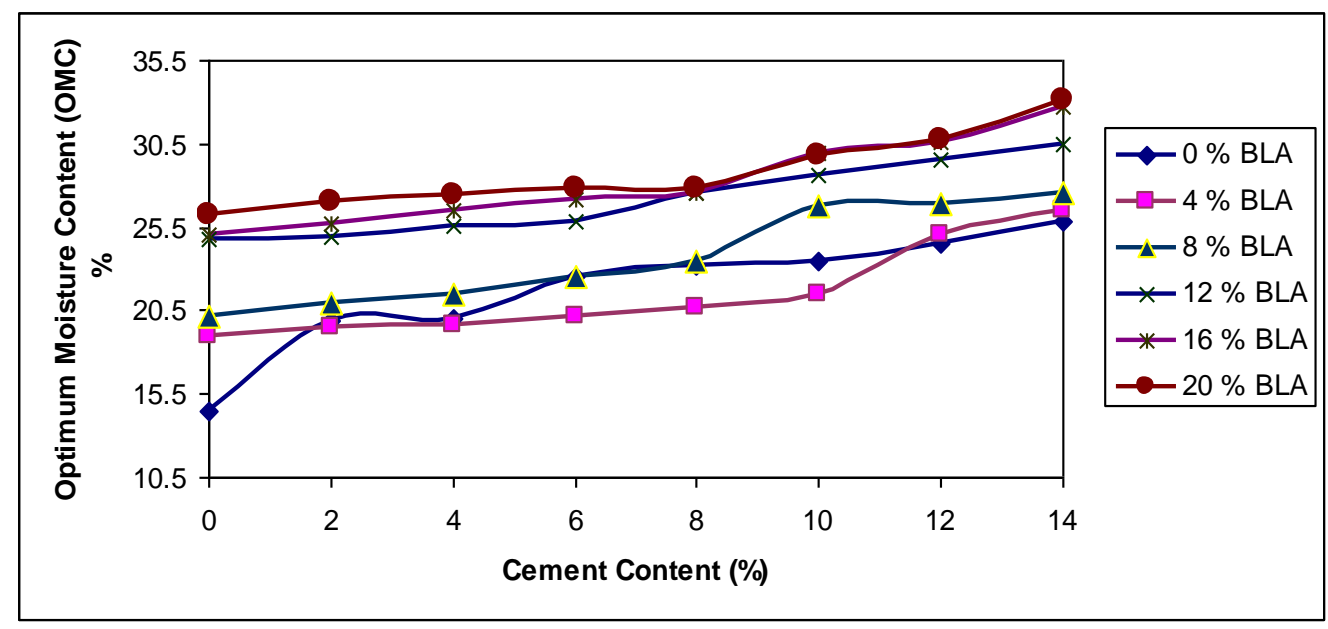

Figure 3: Variation of Optimum Moisture Content of Makurdi Shale treated with Cement and BLA Content.

Effect of Cement - Bamboo Leaf Ash (C BLA) on Unconfined Compression Strength (UCS), California Bearing Ratio (CBR) and Durability: The variation of 7 day UCS with various $\mathrm{C}-\mathrm{BLA}$ content is shown in Figure 4. The results showed increase in 7 day UCS from 53.52 $\mathrm{KN} / \mathrm{m}^{2}$ for untreated Makurdi shale to a maximum value of $1783.92 \mathrm{kN} / \mathrm{m}^{2}$ at $14 \%$ cement $+20 \%$ BLA. The UCS at 7, 14 and 28 days showed improvement as the number of days increased. This showed that C - BLA combination has a long time strength improvement capacity, which implies that progressive increase in strength will enhance the stability of the pavement. 
Am. J. Sci. Ind. Res., 2012, 3(3): 166-174

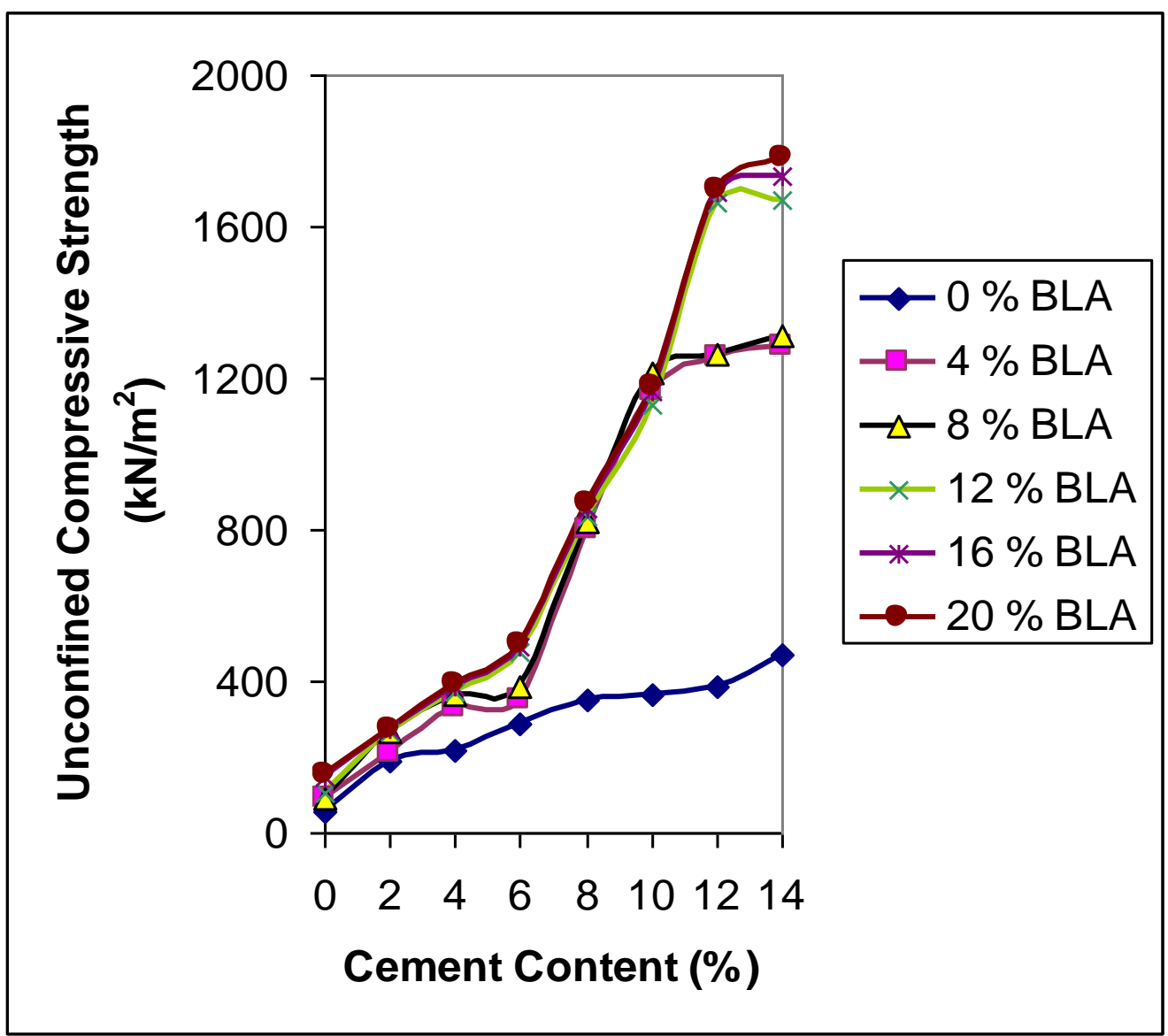

Figure 4: Variation of 7 day Unconfined Compressive Strength (UCS) of Makurdi Shale treated with Cement and BLA Content.

The CBR of Makurdi shale treated with C-BLA showed a similar trend as shown in Figure 5. The CBR increased with C-BLA content, with the peak CBR of $80 \%$ at $14 \%$ cement $+20 \%$ BLA.

Makurdi shale treated with C-BLA mixture offered good resistance to loss of strength as the value of resistance to loss of strength increased with cement and BLA content (Figure 6 ). The highest value of resistance to loss of strength of $95 \%$ was achieved at $14 \%$ cement $+20 \%$ BLA content.

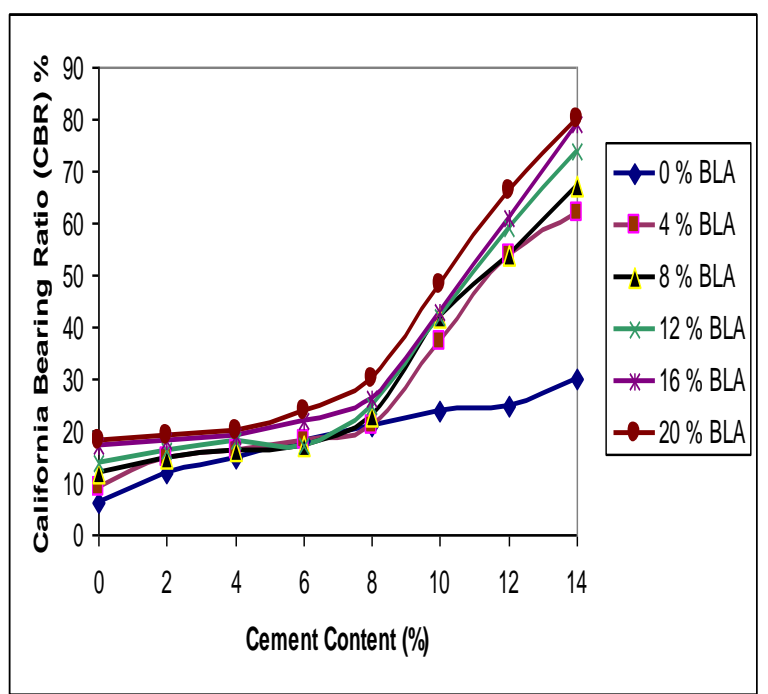

Fig. 5: Variation of California Bearing Ratio of Makurdi Shale treated with BLA and Cement 


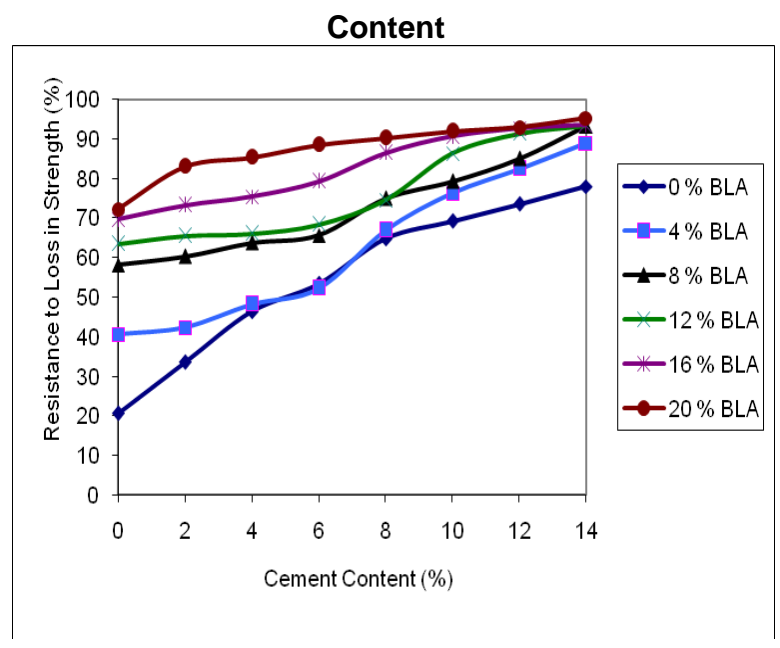

Figure 6: Variation of Resistance to Loss in strength of shale treated with Cement and BLA Content.

\section{CONCLUSION}

The following conclusions can be drawn from the study

- Makurdi shale is an A-7-6 and $\mathrm{CH}$ soil using the AASHTO and USCS classification systems.

- Results showed the ineffectiveness of stabilizing Makurdi shale with only bamboo leaf ash or cement. However, the use of cement - bamboo leaf ash mixture significantly improved the geotechnical properties of Makurdi shale.

- The use of a combination of $14 \%$ cement plus $20 \%$ BLA to treat Makurdi shale yielded CBR and UCS values of $80 \%$ and $1784 \mathrm{kN} / \mathrm{m}^{2}$. Similarly, the combination recorded resistance to loss of strength value of $95.30 \%$.

- Therefore, the use of combinations of 14 $\%$ cement plus $20 \%$ BLA to treat Makurdi shale for use as sub-base material is recommended, using the plant mix method, if economic analysis of alternatives on site justifies its use.

- The Nigeria General Specification (1997) did not specify CBR requirement for the combined use of cement and bamboo leaf ash in soil stabilization, hence results from this study can serve as a guide in the formulation of specifications for the treatment of soil using cement and bamboo leaf ash.

\section{REFERENCES}

Abeyesekera, R. A., Lovell, C. W., and Wood, L. E. (1978). Stress - Deformation and Strength Characteristics of a Compacted Shale Clay Fills. Institution of Civil Engineers, London, pp. 1-14.

Agbede, I. O, and Joel, M. (2011). Effect of Carbide Waste on the Properties of Makurdi Shale and Burnt Bricks made from the Admixtures. American Journal of Scientific and Industrial Research. 2(4):. 670-673.

Agbede, I. O. and Smart, P. (2007). Geotechnical Properties of Makurdi Shale and Effects on Foundations. Nigerian Journal of Technology, 26(2):. 63-73

Amu, O. O. and Adetuberu, A. A. (2010). Characteristics of Bamboo Leaf Ash Stabilization on Lateritic Soil in Highway Construction. International Journal of Engineering and Technology, 2(4):. 212-219.

ASTM (1994). Annual book of ASTM Standard. American Society for Testing and Materials, Vol. 04.08, Philadelphia, Pa.

BS 1377 (1990). Methods of Testing Soils for Civil Engineering Purposes. British Standards Institution, London.

BS 1924 (1990). Methods of Test for Stabilized Soils. British Standards Institution", London.

Dwivedi, V. N., Singh, N. P., Das, S. S. and Singh, N. B. (2006). A New Pozzolanic Material for Cement Industry: Bamboo Leaf Ash. International Journal of Physical Sciences, 1(3), 106-111.

El - Sohby, M. A., Shook, M. A., and Elleboudy, A. M. (1987). Swelling and Shear Strength Characteristics of Mokatta Shale. $19^{\text {th }}$ Regional Conference for Africa on Soil Mechanics and Foundation Engr. Lagos, pp. 143 - 146.

http://en.wikipedia.org/wiki/Makurdi. Makurdi wikipedia the free encyclopedia. Accessed on $6^{\text {th }}$ January, 2012

Joel, M. and Agbede, I. O. (2008a). Effect of Lime on Some Geotechnical Properties of Igumale Shale. Electronic Journal of Geotechnical Engineering, $13(A): .1-12$.

Joel, M. and Agbede, I. O. (2008b). Lime-Sand Stabilization of Igumale Shale Mixtures for Road Work. Nigerian Journal of Engineering, Faculty of Engineering, ABU Zaria, 14 (1):. 16-22.

Joel, M. and Agbede, I. O. (2010). Cement Stabilization of Igumale Shale Lime Admixture for use as Flexible Pavement Construction Material. Electronic Journal of Geotechnical Engineering, 15, 1661-1673.

NBRRI, (1983). "Engineering Properties of Black Cotton Soil of Nigeria and Related Pavement Design". Nigerian Building and Road Research 
Am. J. Sci. Ind. Res., 2012, 3(3): 166-174

Institute Research, Federal Ministry of Works, Lagos, Nigeria Paper, No.1-20.

Nigerian General Specification (1997). General Specification for Bridge and Roads Work. Federal Ministry of Works, Lagos, Nigeria.

Nwajide, C. S. (1982). "Petrology and Paleography of the Makurdi Formation". Unpublished Ph.D Thesis, Department of Geology, University of Nigeria Nsukka.
O' Flaherty C.A. (1974) "Highway Engineering" Vol. 2. Edward Arnold London, p. 95.

USCS, (1962). Unified Soil Classification System for Roads, Airfields, Embankments and Foundations, Military Standard; MIL-STD-619A, US. Dept. of Defence, Washington D.C.

Williams, A. A. B. (1980). Contribution from South Africa on Building on Expansive Soil-General Report Africa on S.M.F.E., Accra, pp. 695-703. 